\title{
THE CRITICAL ASPECT ON FAIR VALUE ACCOUNTING AND ITS IMPLICATION TO ISLAMIC FINANCIAL INSTITUTIONS
}

\author{
Jamaluddin Majid \& Safri Haliding ${ }^{1}$
}

\begin{abstract}
The Critical Aspect on Fair Value Accounting And Its Implication To Islamic Financial Institutions. Fair value accounting (FVA) paradigm replaced the historical cost accounting (HCA) in the development of accounting standards that FVA is more relevant that HCA probably did not provide the real financial and income information. This paper tries to explore critical aspects of the fair value accounting and its implications to Islamic Financial Institutions implications. This study concludes that that fair value accounting measurement provides many critical aspects to be implemented to Islamic Financial Institutions (IFIs). AAOIFI proposed cash equivalent value as respond to fair value measurement that cash equivalent value when the attribute condition are present such as the relevance, reliability and understandability of the resulting information.
\end{abstract}

Keywords: Fair Value Accounting, Islamic Financial Institutions, IFRS, AAOIFI

\begin{abstract}
Abstrak: Tinjauan Kritis Terhadap Nilai Wajar Akuntansi Serta Implikasinya Terhadap Institusi Keuangan Islam. Paradigma nilai wajar akuntansi telah menggantikan penilaian histori akuntansi dalam pengembangan standar akuntansi dimana nilai wajar akuntansi lebih relevan daripada nilai histori akuntansi yang tidak memberikan pembaharuan informasi keuangan dan pendapatan. Penelitian ini mencoba mendalami aspek kritik pada nilai wajar akuntansi dan bagaimana implikasinya pada lembaga keuangan Islam. Penelitian ini menyimpulkan bahwa pengukuran nilai wajar memiliki kekurangan apabila digunakan pada lembaga keuangan Islam. AAOIFI telah menyediakan cash equivalent value $(\mathrm{CEV})$ untuk merespon pengukuran nilai wajar, dimana cash equivalent value lebih memberikan informasi yang relevan, lebih dapat dipercaya dan lebih mudah dipahami.
\end{abstract}

Kata Kunci: Nilai Wajar Akuntansi, Institusi Keuangan Islam, IFRS, AAOIFI

${ }^{1}$ Diterima: 12 April 2014, direvisi: 25 Mei 2014, disetujui: 3 Juni 2014

JamaluddinMajid is an accounting lecturer at Universitas Islam Negeri (UIN) Alauddin, Makassar, email: jamal_majid55@yahoo.com

Safri Haliding, lecturer at Faculty of Economics, Muhammadiyah University of Makassar, Indonesia and part time lecturer at UIN Alauddin Makassar and doing his master in accounting at International Islamic University Malaysia (IIUM). Email: safrihaliding@yahoo.com and safrihaliding@gmail.com 


\section{INTRODUCTION}

Recently, the fair value measurement and its implication in accounting standards have been increasing (Ramanna, 2006). In around the world, including the United States, the United Kingdom, Australia, and the European Union, many jurisdictions of accounting standards have issued standards that fair value is primary recognition of balance sheet and income (Landsman,2006).

One of the important aspects of financial reporting is measurement (Barth, 2007). Barlev and Haddad (2003) state that the fair value accounting (FVA) paradigm replaced the historical cost accounting (HCA) in the development of accounting standards that FVA is more value relevant that HCA probably did not provide the real financial information and income. Therefore, Barlev and Haddad (2003) argue that the measurement of financial reporting should be relevance in regard to some issues in financial reporting such as the stewardship function, agency costs, managementefficiency, and relevant information to stakeholders and workers in terms of social conflict.

However, previously studies mention that fair value accounting suffers from some serious limitations and disadvantages such as issues in market approach, income approach, and cost approach, (for instance: Ball, 2006; Barth, 2007; Deans, 2007; Penman, 2007; Benston, 2008; Ramanna, 2008; Barth and Taylor, 2009; Holban (Oncioiu), and Oncioiu, 2009; So and Smith, 2009; Xia and Monroe, 2010; Jr, 2011).Therefore, Penman (2007) is questioning that whether fair value accounting is really measuring the economic value and market value of businesses activities.

In addition, Al-Yassen and Al-Khadash (2011) argue that accounting standard setters such as the International Accounting Standards Board (IASB) UK and the Financial Accounting Standards Board (FASB) U.S as well as other national accounting standard setters provide high attention and long-term ambition to use fair value accounting as full measurement in all financial instruments. However, regarding to Islamic Financial Institutions (IFIs) that have different objectives and principles as well as have different financial products with conventional financial institution. Therefore, Abdul Rahman (2012) argues that fully adopting International Financial Reporting Standards (IFRS) issued by IFRS-IASB probably there will no specific standards for unique functions of Islamic Financial Institutions. This argument supports previous paper that Ibrahim (2007) states that Islamic Financial Institutions cannot fully comply with IFRS in their financial reporting because Islamic Financial Institutions have some unique requirement.

This paper tries to explore critical aspects of the fair value accounting and its implications to Islamic Financial Institutions implications. The paper is organized 
into four sections. The first section provides the information on fair value accounting and the primary drives of International accounting standard setters. The second section highlights the pros and cons on fair value accounting. This section discusses the critical aspect on fair value accounting. Additionally, this section reviews some implication to financial institutions. The third section reviews the fair value accounting implication to Islamic Financial Institutions. This section also highlights the Islamic Accounting Standards namely Accounting and Auditing Organizations for Islamic Financial Institutions (AAOIFI) and some related issues with regard to Islamic finance products. The next section will focus on the conclusion remarks.

\section{OVERVIEW OF FAIR VALUE ACCOUNTING}

The development of fair value paradigm may take many steps and a number of avenues by accounting profession and the standard setting bodies that probably using a sociological approach and an economic viewpoint regarding to the demand and supply of accounting principles(Berlev and Haddad, 2003).

Therefore, when regulatory bodies adopts a financial reporting paradigm that it becomes the guiding principle for regulation in accounting standards (Hitz, 2007). In terms of the definition of fair value that both US GAAP and IFRS have own explanation with regard to term of fair value accounting. The definitions of fair value based on accounting standard setters' view areas follows:

\section{US GAAP Fair Value Accounting Perspective}

Bragg (2010) published a book that "GAAP 2011, interpretation and application Generally Accepted Accounting Principles”. Bragg (2010) highlights the overview of FVA under GAAP. Moreover, the definition of fair value according to GAAP,ASC 820 that

"the price that would be received to sell an assets or paid to transfer a liability in an orderly transaction between market participants at the measurement date".

In this definition also mentioned that "although GAAP literature has primarily focused on fair value in the context assets and liabilities, the definition also applies to instruments classified in equity" (Bragg, 2010). Regarding to this definition Chea (2011) argues that fair value is market based that in fair value also takes consideration with other market participants for pricing an asset and liability.

In order to understand the concept of fair value that Bragg (2010) highlights the measurement principles and process under ASC 820 into series of steps. The key measurement steps can be listed as follows:

1. Identify the item to be valued and unit account. 
"Specifically identify the asset or liabilities, including the unit of account to be used for the measurement".

2. Determine the principle or most advantageous market and the relevant market participants.

"From the reporting entity's perspective, determine the principle market in which it would sell the assets or transfer the liabilities".

3. Select the valuation premise to be used for asset measurements.

"If the item being measured is an asset, determine the valuation premise to be used by evaluating whether the market place participants would judge the highest and best use of the asset utilizing an "in-use" valuation premise or an "in-exchange" valuation premise".

4. Consider the risk assumptions applicable to liability measurements.

"If the item being measured is a liability, identify the assumptions that market participants would make regarding nonperformance risk including".

5. Identify available inputs.

"Identify the key assumptions that market participants would use in pricing the asset or liabilities, including assumptions about risk".

6. Select the appropriate valuation technique(s).

"Based on the nature assets or liability being valued, the types and and reliability of inputs available, determine the appropriate valuation technique or combination of technique to use in valuing the asset or liability".

7. Make the measurement.

"Measure the asset or liability".

8. Determine amounts to be recognized and information to be disclosed.

"Determine the amounts and information to be recorded, classified, and disclosed in intern and annual financial statements".

According to Shaffer (2011) describes that there are several rules under GAAP that applying fair value accounting. For instance, investment securities and derivative contracts on Statement Financial Accounting Standards (SFAS) no. 115 and SFAS No. 133. Moreover, Shaffer (2011) mentions that the expansion of fair value such as SFAS 195 on hybrid instruments and SFAS 156 on servicing rights in 2006; and fair value option (SFAS 159), business acquisitions (SFAS 141R), and no controlling interests (SFAS 160) in 2007.

In addition, regarding to the purpose of fair value measurement that Bragg (2010) mentions that inputs are the indicators of assumptions, in pricing asset or liabilities is used the market participant as well as assumption with regard to the risk. The inputs are described in hierarchy as follow:

1. Level I Inputs (Directly observable): Quoted prices in active markets for identical 
assets or liabilities that the reporting entity has the ability to access at the measurement date. Such prices are not adjusted for the effects, if any, of the reporting entity holding a large block relative to the overall trading volume (referred to as a "blockage factor").

2. Level II Inputs (Indirectly observable): Directly or indirectly observable prices in active markets for similar assets or liabilities; quoted pricesfor identical or similar items in markets that are notactive; inputs other than quoted prices (e.g., interest rates, yield curves, credit risks, volatilities); or "marketcorroborated inputs.

3. Level III inputs (unobservable): Inputs that are unobservable; that reflect management's own assumptions about the assumptions market participants would make.

\section{IFRS Fair Value Accounting Perspective}

IFRS is one of accounting standard issued by the International Accounting Standards Board as independent organization based in London, UK.

Regarding to definition fair value that based on IFRS (2010) fair value is "the amount for which an asset could be exchanged, or a liability settled, between knowledgeable, willing parties in an arm's length transaction.

Regarding to the definition of fair value that Cairns (2006) criticizes IFRS fair value that there are inconsistency in understanding of the definition and what is and what is not fair value with regard to uncertainties about the application IFRS's fair value definition. For instance, IFRS are entry price or exit price of an asset, liability and equity instrument. It is not clear to determine IFRS. Therefore, Cairns' study (2006) suggests that when the fair value is used to determine the cost and exit price and impairment purpose, entry price should be used.

Ball (2006) states that both IASB and FASB increased over the time the list of implementation of fair value accounting. Moreover, Cairns (2006) indicate that in order to use the fair value, IFRS allow in four steps. The steps as follows:

1. For the measurement of transactions (and the resulting assets, liabilities and equity items) at initial recognition in the financial statements;

2. For the allocation of the initial amount at which a transaction is recognized among its constituent parts;

3. For the subsequent measurement of assets and liabilities; and

4. In the determination of the recoverable amount of assets.

According to Cairns (2006) that it is important to recognize these steps which for the first, second and fourth uses are essential even in the financial statement and for the three uses it is not necessary for using the fair value at the subsequent sheet date. Additionally, Cairns (2006) argues that for all assets, liabilities, and equity 
instruments irrespective, IFRS use the fair value as a generic term whether those are trade on active market or quoted. Therefore, fair value is a subset market value that in active market, it is fair value as determined (Cairns, 2006).

However, regarding to the asset, liabilities, or equity which are not traded in active markets, Cairns (2006) argues that it is likely very difficult, possibly and unreliable to be implemented fair value. Indeed, Cairns (2006) highlights that there is a flexibility in using fair value under IFRS, if the circumstance is less reliable fair value in the initial measurement of an asset or liabilities that IFRS-standards prohibit to use fair value in unreliable circumstance (see: IAS 38 intangible assets and IAS 39 equity instrument).

Recently, Standard setters accounting both US GAAP and IFRS are continuing to develop for expanding the use of fair value (Shaffer, 2011). Interestingly, International Accounting Standard Board (IASB) releases the proposal on accounting for financial instrument that this proposal uses the approach of fair value by mixing the measurement of U.S GAAP and IFRS that IASB and FASB tried to provide the new fair value as mixed measurement between US GAAP-FASB and IFRS-IASB (Shaffer, 2011).

In addition, the new development of fair value between FASB and IASB takes many attentions and responses among practitioners, investors, academics and regulator. Therefore, the FASB and IASB continue their proposals to re-deliberate as response from feedback and reconcile the differences between fair value under IASB and FASB (Shaffer, 2011).

Penman (2007) argues that since both IASB and FASB standards provide fair value as mandatory for measure the assets and liabilities, the issues in fair value probably are when and how should be applied that fair value is far from resolved.

Shaffer' study (2011) finds that in the approach of FASB closely mirrors the IASB's proposed measurement model. For instance, firms are allowed to amortized cost to measure the instruments principally of cash flowwhich being held for collection or payment such as loans, deposits and debt).

\section{THE DEBATING IN FAIR VALUE ACCOUNTING}

This section discusses the critical aspect on fair value accounting both US GAAP and IFRS. Additionally, this section reviews some implication to financial institutions.

Regarding to the issues in fair value that Penman (2007) indicates some preliminaries with regard to what is fair value? And fair value to whom? Regarding to fair value to whom that Penman identifies some notions in fair value. The notions 
of what is fair value as follows (Penman S.H, 2007):

1. Fair value variously applied in a 'mixed attribute model': fair value is used alternatively with historical cost for the same asset and liability but at different time.

2. Fair value continually applied as entry value: asset are revalued at their replacement cost, with current costs then recorded in the income statements, with unrealized (holding) gains and losses also recognized.

3. Fair value continually applied as exit value: asset and liability are remarked each period to current exit price, with unrealized gains and losses from remarking recorded a part of income.

In this light, Penman (2007) argues that for the notions 1 and 2 in application could be debated due to both are really modified cost accounting, standard revenue recognition and applying exit price on actual exit of the product to the market, however, notion 3 applies exit prices values but with-out actual exit (realization).

In addition to fair value to whom,Penman (2007) indicates that the demand probably plays important that different users may different demand for accounting report. For instance, in the case of a creditworthiness deteriorates the shareholder probably use the value a fall in the market value in order to recognize the gain, but not the creditor that the bank may use the bank deposits at fair value, not the deposits (Penman, 2007).

Moreover, in bank regulator perspective that if the reporting affected the depositors' confidence in the banking system, the bank regulator may use the value is less than face value while investor uses the fair value information with regard to volatility, not so a central banker focuses on feedback effects on systematic risk that during the speculative times the a bank regulator focuses on marking up banks' capital (Penman, 2007). Therefore, fair value provides different demand with different perspective depend on its perspective of users.

\section{Fair Value under SFAS 157 US GAAP}

Regarding to fair value definition under US GAAP, Benston (2008) identifies that the new definition of fair value as stated in 5 of SFAS 157 provides two issues: firstly, fair value is the exit value of asset and liability, secondly, fair value is often not based on actual market transactions. Similarly, Penman (2007) states that there are two questions with regard to the FASB and IASB fair value: firstly, whether exit value measures value to shareholders and at the level aggregate whether fair value is applicable.

Regarding to the shortcoming of SFAS 157 fair value measurement that Benston (2008) highlights the shortcomings of US GAAP fair value. The following 
shortcomings are:

1. Fair values not based on actual market prices are costly to determine and verify.

2. Value in use and entrance value are used, contrary to SFAS 157-specifieds exit values.

3. Transaction costs are used, contrary to SFAS 157.

4. Fair value for inventories and fixed assets that may be included in business combinations present problems that are not recognized.

5. Fair value other than level 1 could be readily manipulated and difficult to verify.

Therefore, based on the above shortcomings of SFAS 157 Benston (2008) asserts that there are some problems and cost of constructing, recording, and presenting the required numbers in implementing the guideline SFAS 157 US GAAP fair value measurement. Moreover, Benston (2008) concludes that FASB uses the fair value in order to make the relevance of the numbers presented in financial statements to satisfy the users. This is supported in the statement of SFAS 157 that "should provide users of financial statements (present and potentialinvestors, creditors and others) with information that is useful in making investment,credit, and similar decisions" (Benston, 2008).

SFAS 157 provides the hierarchy inputs in order to measure from the most to least reliable into fair value measurement (Ryan, 2008). In addition to the level inputs that Penman (2007) identifies the pluses and minuses regarding to the implementation of inputs lever 1, 2, and level 3.The pluses and minuses of level inputs as follows:

\section{Pluses and minuses of level 1 fair value measurement}

Penman (2007) argues that there is a subjective estimate of fair value of asset and liability for shareholders with regard to the idea of accounting information probably is based on the objective, reliable evidence. Therefore, Penman provides the plus and minus with regard to level 1 :

The Plus: "fair (market) values are a plus when value to shareholders is determined solely by exposure to market price; that is, shareholder value is one-to-one with market prices".

The Minus: "fair (market) values are a minus when the firm arbitrages market prices that is, fair value is not appropriate when the firm adds value (for shareholders) by buying at (input) market prices and selling at (output) market prices".

\section{Pluses and minuses of level 2 and 3 fair value measurement}

Level 2 and 3 provide the estimates of hypothetical market price which there is a subjective estimate in this objectivity of those levels (Penman, 2007). 
For this level 2 and 3 Penman highlights how important the integrity of managers with regard to the potential their subjective biases in using this levels as well as the effectiveness of the control is very important such as the independence and competence of monitors-auditors, assessor and corporate boards.

With regard to the estimated fair value that Penman (2007) provides that plus and minuses of level 2 and 3 fair value measurement. Those are as follows:

1. Fair value accounting applies only when shareholder value is solely determined by exposure to market prices means that, in most cases, there will be an active market where Level 1 measurements are available.

2. One must question whether Level 3 really enforces a discipline in estimating market prices.

3. Fair value estimation errors introduce error into the balance sheet but also the income statement (which reports the change in fair value).

4. Historical cost involves estimates and estimated fair values are nodifferent.

5. Historical cost estimates true up against the actual transaction record, and usually fairly quickly.

6. An analyst will have difficulty in carrying out a quality analysis on fair value accounting.

7. The observed market behavior is instructive.

8. The informative of fair values declines as estimates are introduced.

To sum up, based on the discussion, my opinion to fair value implications that fair value accounting provide pros and cons among researchers that the main weakness of the fair value is not indicating as the value of the measurement date at large that measurement probably could be manipulate due to subjective estimates. Therefore, it provides the bad implication to economics decision regarding to substantial uncertainty in fair value measurement.

\section{Fair Value Accounting IFRS}

Regarding to fair value accounting that IASB provides conceptual framework as guidance. However, Barth (2007) states that with regard to accounting measurement, IASB's framework is not providing much guidance such as historical cost and settlement value, measurement technique, such as present value that there is no properly guidance to choose among.

In terms of the objective of financial reporting that Barth (2007) quoted from IASB in 2006, Para. OB2 as 'to provide information that is useful to present and potential investors and creditors and others in making investment, credit, and similar resource allocation decisions'.

In this light, Barth (2007) argues that the objective of financial reporting as 
provided in IASB seems focus on investors or investing decision that the terms of 'investor' in objective of financial reporting refers to present and potential equity holders and their advisers, the term 'creditor' refers to present and potential lenders and their advisers.

The implementation of IASB seems providing some misunderstandings with regard to decision due to accounting measurement in the real-world economic phenomena do not specify how to measure the real economics. For instance, not all expected inflow and outflows are assets and liabilities in real economics for financial statements purposes (Barth, 2007). Therefore, Barth highlights some common misunderstandings about the IASB approach. The misunderstandings as follows (Barth, 2007):

1. The Framework does not identify conservatism as a qualitative characteristic of decision-useful financial information.

"Conservative amounts are not neutral, which is a qualitative characteristic that neutralitymeans freedom from bias. Conservatism implies a negative bias for assets and income and a positive bias for liabilities and expenses"

2. Matching is not a separate concept in the Framework.

"Matching is not an objective of accounting recognition or measurement that the Framework is based on the notion that if assets and liabilities are appropriately recognized and measured, profit or loss will be too, which obviates the need for a separate concept of matching. However, the application of the matching concept under this Framework does notallow the recognition of items in the balance sheet which do not meet the definition of assets or liabilities".

3. The term reliability as used in the current Framework is neither limited to verifiability, as some interpret it, nor does it mean precision.

"This common misunderstanding is why the preliminary views document (IASB, 2006a) uses the term 'faithful representation' rather than 'reliability' and explains that just because an amount can be calculated precisely, it is not necessarily a faithful representation of the real-world economic phenomenon it purports to represent. Faithful representation implies neither absolute precision in theestimate nor certainty about the outcome"

4. The objective of financial reporting does not include providing accounting information for

management to use in managing the business or for contracting parties to include in contracts.

"This is because these users can directly specify the information they want and need. IASB standards are designed for general purpose financial reports, whose objective stems from the information needs of external users who lack the ability 
to prescribe all the financial information they need from the entity".

5. The Framework focuses on defining financial position elements, i.e., assets and liabilities, not because financial position is more important than profit or loss. "It is because profit or loss is important. Defining financial position elements is the only way standard setters have been able to determine how to measure revenues and expenses, which comprise profit or loss".

6. The IASB does not have an objective to measure all assets and liabilities at fair value.

"As explained in Section 3, there are reasons why fair value is a candidate measurement basis in many situations, and the IASB and FASB have a stated long-term objective to measure all financial assets and liabilities at fair value".

\section{The Advantages Fair Value Accountingof IFRS for Investors}

With regard to advantages fair value to investors that Ball (2006) highlights the potential advantages. These are as follows:

1. IFRS promise more accurate, comprehensive and timely financial statement information, relativeto the national standards they replace for public financial reporting in mo.st of the countries adopting them.

"Financial statementinformation is not known from other sources, this should lead to more-informed valuation in the equity markets and hence lower risk to investors".

2. Small investors are less likely than investment professionals to be able to anticipate financial

statement information from other sources.

"Improving financial reporting quality allows them to compete better with professionals, andhence reduces the risk they are trading with a better-informed professional (known as 'adverse selection')".

3. By eliminating many international differencesin accounting standards, and standardizing reportingformats, IFRS eliminate many of the adjustments analysts historically have made in

order to make companies" financials morecomparable internationally.

"IFRS adoption therefore could reduce the cost to investors of processing financial information. The gainwould be greatest for institutions that create large, standardised-format financial databases"

4. A bonus is that reducing the cost of processing financial information most likely increases the efficiency with which the stock market incorporates it in prices. "Most investors can be expected to gain from increased market efficiency".

5. Reducing international differences in accounting standards assists to some degree in removing barriers to cross-border acquisitions and divestitures, which 
in theory will reward investors with increased takeover premiums.

\section{The Disadvantages Fair Value Accountingof IFRS for Investors}

Regarding to the potential problems of fair value to investors that Ball (2006) highlights the potential problems. These are as follows:

1. Market liquidity is a potentially important issue in practice. Spreads can be large enough to

cause substantial uncertainty about fair valueand hence introduce noise in the financial statements.

2. In illiquid markets, trading by managers can influencetraded as well as quoted prices, and

hence allows them to manipulate fair value estimates.

3. Worse, companies tend to have positively correlatedpositions in commodities and financial

instruments, and cannot all cash out simultaneouslyat the bid price, let alone at the ask. Fair value accounting has not yet been tested by amajor financial crisis, when lenders in particularly could discover that 'fair value' means 'fairweather value".

4. When liquid market prices are not available,fair value accounting becomes 'mark to model'accounting

5. If liquid market prices are available, fair valueaccounting reduces opportunities for self-interestedmanagers to influence the financial statementsby exercising their discretion overrealizing gains and losses through the timing ofasset sales.

To summary, based on the above discussion, my opinion to fair value implications that fair value with regard to IFRS that may bring accurate to business decision with more attention and advantages to investor as supported in objective of IASB. However, fair value of IFRS fails to fully acknowledge the significance between liquid and illiquid marker similarly to US GAAP fair value that provides uncertainty (gharar) and leading to subjective estimates as well.

\section{ISLAMIC PERPECTIVE OF ACCOUNTING MEASUREMENT}

Since, Islamic Financial Institutions (IFIs) established that have different objectives and principles as well as have different financial products with conventional financial institution. Therefore, Abdul Rahman (2012) argues that fully adopting International Financial Reporting Standards (IFRS) issued by IFRSIASB probably there will no specific standards for unique functions of Islamic Financial Institutions. Indeed, in 1992, the Accounting and Auditing Organization for Islamic Bank and Financial Institution (AAO-IBFI) now called Accounting and 
Auditing Organization for Islamic Financial Institution (AAOIFI) was established as respond to the establishment of Islamic banks and Islamic Financial Institutions (Karim, 1995).

First of all, AAOIFI developed the objective of financial reporting. The objective is different compared to the accounting standard-setting bodies such FASBUS GAAP and IASB-IFRS. Based on the AAOFI (2010) one of main objectives as follows:

"To determine the rights and obligations of all interested parties, including those rights and obligations resulting from incomplete transactions and other events, in accordance with the principles of Islamic Shariah its concepts of fairness, charity and compliance with Islamic business values"

And one of main objectives with regard to financial reports "information about Islamic bank's compliance with the Islamic Shariah and its objectives and to establish such compliance and information establishing the separation of prohibited earning and expenditures, if any which occurred, and of the manner in which these were disposed of"

Regarding to objective of IFIs, Rasid, Abdul Rahman and Ismail (2011) point out that the main differences between IFIs and conventional financial institutions is the principles as objectives which need to be compliance based on shariah (jurisprudence and Islamic ethics). The Principles such as 1.Prohibition of riba, 2.Application of al-bay (trade and commerce), 3.Avoidance of gharar (ambiguities) in contractual agreements, prohibition of maisir (gambling), 4.Prohibition of conducting business involving prohibition commodities.

Since, Islamic Financial Institutions have differences objectives and principles as compared to conventional counterpart. Therefore, IFIs come up with specifically accounting for Islamic Institutions. For instance, accounting for Islamic Banks with regard to Zakat, murabahah, mudahrabah, ijarah and other Islamic banking contracts. However, Yaya (2004) argues that in terms of Islamic Accounting's objectives of The AAOIFI, the contents and goals are likely the same with currently conventional accounting that focus on providing information system for users.

Abdul Rahman (2003) argues that accounting on Islamic perspective in Muslim society, in way of accountant to provide the financial information to user is not only as service to the users and public at large, but information is provided to society must take consideration to accountability in order to follow the God's commandments.Lewis (2001) argues that Islamic accounting may follow the shariah law in terms of theaccounting principles and postulates in order to develop the proper accounting theory.

In my point of view that fair value accounting provides benefit to economic 
decision for shareholders. However, in essence to Islamic Financial Institutions those economics decisions is not the main objective to Islamic Financial Institutions, compliance to shariah and bringmaslahah to society need to notice before making economic decisions.

Therefore, Islamic principles are crucial issues in Islamic financial Institutions. Regarding to accounting principles from Islamic perspective, Ahmed (1994) states that accounting in Islamic principles should govern with financial dealing and contracts based on Islamic objective such as realization of fairness and justice, preservation of the rights and dues of all parties, paying Zakat (that necessitates having accurate and just financial statements which represent accurately and truly the financial position of the entity).

In this light, AAOIFI (2010) under SFA no. 2 with regard to the concepts of Financial Accounting for Islamic Banks and Financial Institutions states that "concepts of accounting measurement in measurement attributes refer to the attributes of assets and liabilities that should be measured for financial accounting purposes". In addition to measurement attributes that AAOIFI indicates to "the cash equivalent value expected to be realized is the number of monetary units that would be realized if an asset was sold for cash in the normal course of business as of the current date" (AAOIFI,2010,para. 89). However,SFA no. 2 AAOIFI (2010, para.89) refers to cash equivalent value when the attribute condition are present such as the relevance, reliability and understandability of the resulting information.

In this regard, SFA, no. 2 AAOIFI (2010, para.89) states that cash equivalent value specifically would be suitable as basis for accounting measurement for an Islamic banks as the condition for Islamic banks' products such as mudarabah and investment accounts. In addition to cash equivalent value that FAS no. 2 AAOIFI (2010) argues that reliable and comparable information are very important to unsure the measurement of cash equivalent value. Therefore, SFA no. 2 AAOIFI (2010) indicates some principlesduring the revaluation assets, liabilities and restricted investments. The principles are as follows:

a. To the extent available, outside indicators (such as market prices) should be used.

b. All relevant information whether positive or negative should be utilized.

c. Logical and relevant valuation method methods should be utilized.

d. Consistency in the use of valuation methods should be adhered to.

e. To the extent appropriate, experts in valuation should be utilized.

f. Conservatism in the valuation process by adhering to objectivity and neutrality in the choice of value (SFA no.2. AAOIFI, para. 95). 
In light this, Al-Sadah (2000, p.42) points out as quoted in Napier (2007) that "the majority of Islamic banks represented on the AAOIFI accounting standards board strongly rejected adopting the cash equivalent value approach, since this accounting treatment would exert pressure on the banks to pay out a higher level of profits to shareholders and investment account holders if the bank recognized the unrealized gains".

However, AAOIFI provides historical cost as a recommendation to alternative measurement attribute to the cash equivalent value. Particularly, AAOIFI refers to its fair value at the date of its acquisition including amounts incurred to make it usable or ready for disposition (SFA no. 2. AAOIFI para.98; Abdul Rahman, 2010. Page. 31).

\section{The Implication to Islamic Financial Institutions}

Islamic financial institutions (IFIs) and Islamic Banking (IB) have special characteristics. For instance, Islamic banks are not using interest on lending and borrowing money(Karim, 2001). Moreover, Napier (2007) indicates that Islamic Banks provides profit-loss sharing instruments such mudarabahah and musharakah and mark-up instruments such as murabahah, ijarah and salam. Since, the Islamic banks and IFIs have different characteristic to counterpart of conventional banks. Therefore, probably IFIs and (IB) have different consequence to accounting principles and regulation to govern the financial transaction based on the Islamic objectives and principles.

\section{Issues in Gharar in Fair Value}

As noted on previously discussion to fair value accounting problems. Ball (2006) points out that "Market liquidity is a potentially important issue in practice. Spreads can be large enough to cause substantial UNCERTAINTY about fair value and hence introduce noise in the financial statements".

In Islamic perspective, uncertainty means as a gharar that one of the principles of Islamic Financial Institutions is to avoid of gharar (ambiguities) in contractual agreements or no gharar involve business transactions(Rasid et al 2011). Lewis (2001) argues that in business terms, gharar means "to undertake a venture blindly without sufficient knowledge or to undertake an excessively risky transaction". Additionally, gharar transaction provides a potential speculation in business terms. For instance, investment trading for futures on stock markets (Lewis, 2001).

In addition, Malia, Casson and Napier (2006) note that unlawful transaction in Islamic Financial Institutions violates Islamic principles such hedging or optional transaction which contains excessive risk (gharar). Therefore, Malia et al (2006) 
suggest that Islamic banks should not enter into unlawful transaction in order to compliance to shariah and follow Islamic principles.

According to AlQuran Al Baqarah 2:282 "O ye who believe! When ye deal with each other, in transactions involving future obligations in a fixed period of time, reduce them to writing; let a scribe write down faithfully as between the parties...". Based on this verses that all muslims transaction must be recorded as to show the importance of fulfill rights and obligationsin order to reduce the doubt and uncertainty (gharar) in inter-personal arrangements(Napier, 2007).

Based on above discussion regarding to gharar in fair value. Therefore, my argument that when fair value provides uncertainty or gharar in measuring the asset and liabilities in certainty conditions. For instance, level 2 and level 3 of fair value which provides subjective estimates (see, Penman, 2007) that violate Islamic principles, meaning that fair value is not shariah compliance at certain circumstance. Therefore, Islamic banks or Islamic Financial Institutions need to reduce in adopting fully fair value. Otherwise, cash equivalent value is the best choice for Islamic banks as recommended by AAOIFI.

\section{Issues in Zakat}

Many studies argue that the implication of accounting measurement to Islamic Financial Institutions refers to Zakat valuation (for instance:Ahmed, 1994; Adnan and Graffikin, 1997;Mirza and Baydoun, 2000;lewis, 2001; Abdul Rahman, 2003;Yaya, 2004;Lewis, 2006). Moreover, Yaya (2004) argue that Islamic accountability in accounting is crucial and Zakat as a primary objective in Islamic accounting and accountability. His argument supported by such as Adnan and Graffikin(1997); Lewis (2006) and Abdul Rahman (2007;2010).

In this regard, Mirza and Baydoun (2000) argue that the measurement of assets with regard to Zakat is important issue from Islamic perspective. Hence, according to Mirza and Baydoun (2000) in order to measure the amount of Zakat, need to use the contemporary time not in historical cost.Mirza and Baydoun (2000) suggest that re-value the assets regularly is needed and Islamic accounting system probably uses both historical and market selling prices with regard to enable firms to accommodate contracts and to discharge with social responsibility.

In addition, Adnan and Gaffikin (1997) argue as quoted in Yaya (2004) that there is no room in Islamic financial institutions to use the concept of historical cost and conservatism due to the issues in misleading and quality of justice and honesty of financial information.

Abdul Rahman (2007) argues that fair measurement of Zakat paid by 
corporation is one important issue as Zakat for business wealth. In addition, Abdul Rahman (2007) mentions that business wealth should pay the Zakat including in business activities which involves such as trade goods (or stock on trade), cash in hand or at bank, debt or credit extended to customers or others.

Regarding to Zakat, AbdulRahman's study (2007) found that in case of Zakat in the Malaysia context, IFIs should reports: 1. The amount of Zakat due or paid; 2. The method of Zakat measurement used; 3. The ruling of Shariah supervisory board in matters to pertaining Zakat; and 4. The obligation on Zakat due from the subsidiaries, the equity investment account, and other investment account (in case of Islamic banks). Moreover, Abdul Rahman (2007) points out with regard to Zakat practices that there is a lack of information provided to the users of the annual reports.

Regarding to Zakat that AAOIFI provides in FAS no. 9 that discussing issues in standard accounting treatment of Zakat base and disclosure requirement. Regarding to determination of Zakat AAOIFI FAS no. 9. Para.2 states that "the Zakat base shall be determined by using $2.5 \%$ for a lunar calendar year and $2.5775 \%$ for a solar calendar year based on either of the following two methods: Net Assets, Net Invested Funds". Moreover, Zakat should be measured at cash equivalent value as recommend by AAOIFI FAS no.9. para. 5. However, AbdulRahman (2007)asserts that AAOIFI under FAS no.9 did not provide the specific regarding to charge the net receivables.

In addition, in terms of the treatment of Zakat in financial statements FAS no.9.para. 9 AAOIFI: case in which the Islamic bank is obligated to pay Zakat:

"In any of the following cases, Zakat shall be treated as a (non-operating) expense of the Islamic bank and shall be included in the determination of the income statement:

(a). When the law requires the Islamic bank to satisfy the Zakat obligation.

(b). When the Islamic bank is required by its charter or by-law to satisfy the Zakat obligation.

(c). When the general assembly of shareholders has passed a resolution requiring the Islamic bank to satisfy the Zakat obligation.

Abdul Rahman (2007) states that issues in fairness in Zakat are very important such as providing justice to both Zakat payer and Zakat recipient respectively. Wahab and Abdul Rahman (2011) indicate that due to distribution of Zakat fund that there are many shortcomings that influence significantly payment to Zakat institutions. Therefore, Islamic accountability on accounting is important as well as 
transparency in Islamic financial Institutions.Additionally, Abdul Rahman (2007) indicates that in Islamic perspective the preparation of financial information need to take consideration to Zakat purpose.

\section{IFRS vs. AAOIFI: The Competition of accounting standards?}

Abdul Rahman (2012) argues that fully adopting International Financial Reporting Standards (IFRS) issued by IFRS-IASB probably there will no specific standards for unique functions of Islamic Financial Institutions ${ }^{2}$. This argument supports previous paper that Ibrahim (2007) states that Islamic Financial Institutions cannot fully comply with IFRS in their financial reporting because Islamic Financial Institutions have some unique requirement.

Karim (2001) points out that there is increasing interest to provide the harmonization of accounting and financial reporting by banks. For instance, international Accounting Standards Committee (IASC) to issue international accounting standard (IAS), Basle Committee and United Nation regarding to issues in transparency and comparability.

In terms of banking regulation of Islamic banks that Karim (2001) argues that the implication of the unique characteristic of Islamic banks seems that did not get higher support from the supervisory bodies in the countries in which Islamic banks operated. For instance, due banking system, the system is same both Islamic and conventional banks that there is no particular standard or regulation to apply to Islamic banks (Karim, 2001).

With regard to IFRS that many countries as well as Muslim countries in which Islamic banks operated seem to be consistent to adopt the IFRS. For instance Indonesia, Malaysia use IFRS as a future core accounting standards. Concerning to issues in IFRS vs. AAOIFI,Ibrahim (2007) claims that there are many issues relate to conflict in convergence with the global International Reporting Standards that may not appropriate with the spirit of global accounting standards convergence.

Additionally, Ibrahim (2007) indicates that the issues currently move to seriously debate on convergence of accounting standards from harmonization to hegemonic tone of standardization. Ibrahim argues that IFRS seems to be arrogant as Ibrahim states "the preface to the recent International Financial Reporting Standards which states that financial statements cannot state that they comply with international

2 This argument is taken from slides in class for subject Islamic accounting and finance (ACC 6810) on subtopic Islamic accounting Practice-Accounting for Islamic Finance prepared by Professor Dr.Abdul Rahim Abdul Rahman in 2012, Professor accounting at International Islamic University Malaysia (IIUM). 
financial reporting standards unless they comply with all the applicable standards and not some of them. Hence, IFRS permits no exceptions and is Busherian in tone, "either you are with me or are against me!"

In light this, AAOIFI provides promulgate accounting, auditing and governance standards that there are 14 accounting standards as well as the statements which provide a conceptual framework that guides the preparation standards (Karim, 2001). However, AAOIFI's standards seems tobe failin implementing in which Islamic banks operated that there is lack of appreciation by agencies (Karim, 2001). Probably, many issues involved with regard to accounting standard-setting.

Karim (2001) indicates that the acceptance for AAOIFI for worldwide may tend to challenge the adherence to IASs to achieve international harmonization in financial reporting regardless of cultural differences that probably there is no collaborative productively among regulatory bodies.

In terms of the growth of Islamic finance that KPMC-audit firm (member of big 4) and the Association of Chartered Certified Accountants (ACCA) (2010) report for potential development of harmonizing financial reporting of Islamic finance that the report provides possible approaches. The approaches as follows:

\section{IFRSby default}

"IFRS could be used as the default reporting framework, although guidance based on existing Islamic financial reporting models would need to be used to supplement the standards for those IF transactions that do not fit simply into the framework".

\section{Islamic accounting standards by default}

"Alternatively, a set of globally recognized Islamic accounting standards could be used by IFIs. Where possible these would be based on IFRS, but would include specific recognition, measurement, presentation and disclosure requirements relevant to Islamic finance products and transactions".

To sum up, my personal opinion that probably, the collaboration productively among regulatory bodies is the best way to produce harmonizing financial reporting of Islamic finance and implication to Islamic Financial Institutions because the successfully of harmonizing Islamic finance's financial reporting needs supports from international bodies such as business organizations and professional organizations as well as governments that IFRS has been proved how to get international recognition. Therefore, AAOIFI may need to learn from IFRS' experiences as accounting standards-setting. 


\section{CONCLUSION}

The paper indicates that fair value accounting measurement provides many critical aspects to be implemented to Islamic Financial Institutions (IFIs) that Islamic bank do not provide interest on business transaction that considered as unique characteristics with profit loss sharing schemes. Additionally, AAOIFI proposed cash equivalent value as respond to fair value measurement that cash equivalent value when the attribute condition are present such as the relevance, reliability and understandability of the resulting information.

Regarding to AAOIFI's standards that Karim (2001) argues AAOIFI's standards seems to be fail in implementing in which Islamic banks operated that there is lack of appreciation by agencies. Therefore, Abdul Rahman (2012) argues that fully adopting International Financial Reporting Standards (IFRS) issued by IFRS-IASB probably there will no specific standards for unique functions of Islamic Financial Institutions. In addition, the paper may be recommended to work together among Muslim countries to unity the potential harmonizing one set accounting standards for Islamic Financial Institutions. For instance, AAOIFI's standards.

\section{REFERENCES}

AAOIFI.FAS No. 2. 2010. Accounting and Auditing Standards for Islamic Financial Institutions. Manama, Bahrain: Accounting and Auditing Organization for Islamic Financial Institutions.

AAOIFI.FAS No. 9. 2010. Accounting and Auditing Standards for Islamic Financial Institutions. Manama, Bahrain: Accounting and Auditing Organization for Islamic Financial Institutions.

Rahman A.R.A. 2003. Ethics in Accounting Education: Contribution of the Islamic Principle of Maslahah, IIUM Journal of Economics and Management, 11(1), 1-18.

2007. Pre-Requisites for Effective Integration of Zakat into Mainstream Islamic Financial System in Malaysia. Islamic Economic Studies, 14(1\&2), pp. 91-107. 2010. An Introduction to Islamic Accounting Theory and Practices. CERT Publication, Kuala Lumpur, Malaysia.

2012. Islamic Accounting Practices-Accounting for Islamic Finance. Slides of Islamic Accounting and Finance (ACC 6810) semester 1 2012/2013. Accounting Department, International Islamic University Malaysia.

Adnan, M. A. \& Gaffikin, M. 1997. The Shariah, Islamic Banks andAccounting Concepts and Practices. Paper Presented at Accounting, Commerce and Finance: The 
Islamic Perspective International Conference. Sydney, Australia.

Ahmed, E. A. 1994. Accounting Postulates and Principles from an Islamic Perspective. Review of Islamic Economics, 3(2), pp. 1-18.

Al-Yaseem, B. S \& Al-Khadash, H. A. 2011. Risk Relevance of Fair Value Income Measures Under IAS 39 and IAS 40. Journal of Accounting in Emerging Economies, 1(1), pp. 9-32.

Bakar, N.B.A \& Rahman, A.R.A. 2007. A Comparative Study of Zakat and Modern Taxation. Journal of Islamic Economics King Abdul Aziz University, 20(1), pp. 25-40.

Ball, R. 2006. International Financial Reporting Standards (IFRS): Pros and Cons for Investors. Accounting and Business Research, International Accounting Forum, pp. 5-27.

Barth, M \& Taylor, D. 2010. In Defense of Fair Value: Weighing the Evidence on Earning Management and Asset Securitizations. Journal of Accounting and Economics, 49, pp. 26-33.

Barlev, B \& Haddad, J. R. 2003. Fair value Accounting and the Management of the Firm. Critical Perspectives on Accounting, 14(4), pp. 383-415.

Benston, G. J. 2006. Fair-Value Accounting: A Cautionary Tale from Enron. Journal of Accounting and Public Policy 25(4), pp. 465-484.

2008. The Shortcoming of Fair-Value Accounting Described in SFAS

157. Journal of Accounting and Public Policy, 27, pp. 101-114.

Bragg, S. M. 2010. GAAP 2011 Interpretation and Application of Generally Acceptanced Accounting Principles. New Jersey, the United States of America: John Wiley $\&$ Sons.

Broadley, P. 2007. Discussion of 'Financial Reporting Quality: is Fair Value A Plus or A minus?.Accounting and Business Research, pp. 45-48.

Cairns, D. 2006. The Use of Fair Value in IFRS. Accounting in Europe, 3, pp. 6-22.

Chea, A. C. 2011. Fair Value Accounting: Its Impacts on Financial Reporting and How It Can Be Enhanced to Provide More Clarity and Reliability of Information for Users of Financial Statements. International Journal of Business and Social Science, 2(20), pp. 12-18.

Deaconu, A \& Buiga, A. 2010. Analysis of the Convergence Degree Between the Accounting and the Valuation Standards Concerning Fair Value. Journal of Property Investment and Finance. 28(5), pp. 365-384.

Dean, S. 2007. Discussion of 'Fair Value Accounting Information Relevant and Reliable? Evidence from Capital Market Research?'.Accounting and Business Research, pp. 31-32. 
Hijazi, S \& Tayyebi, A. 2010. Accountancy Futures, Harmonising Financial Reporting of Islamic Finance. Paper Report's KPMG and ACCA.

Hitz, J-M. 2007. The Decision Usefulness of Fair Value Accounting-A Theoretical Perspective. European Accounting Review, 16(2), pp. 323-362.

Karim, R. A. A. 1995. The Nature and Rational of Conceptual Framework for Financial Reporting by Islamic Banks. Accounting and Business Research, 25(100), pp. 285-300.

2001.International Accounting Harmonization, Banking Regulation, and Islamic Banks. The International Journal of Accounting, 26, pp. 169-193.

Lewis, M. K. 2001. Islamic and Accounting. Accounting Forum, 25(2), pp. 103127.

2006. Accountability and Islam. Paper Presented at Fourth International Conference on Accounting and Finance in Transition. Adelaide: Australia.

Maali, B, et.al. 2006. Social Reporting by Islamic Banks. ABACUS, 42( 2), pp. 266289.

Mirza, M \& Baydoun, N. 2000. Accounting Policy Choice in ARiba-Free Environment. Accounting, Commerce \& Finance: The Islamic Perspective Journal. 4(1\&2), pp. 30-47.

Ramanna, K. 2008. The Implication of Unverifiable Fair-Value Accounting: Evidence from Political Economy of Goodwill Accounting. Journal of Accounting and Economics, 45, pp. 253-281.

Shaffer, S. 2011. Evaluating the Impact of Fair Value Accounting on Financial Institutions: Implication for Accounting standards Setting and Bank Supervision. Working Paper No. QAU 12-01. Boston: Federal Reserve Bank.

Smith, M \& Stella, S. 2009. Value-Relevance of Presenting Changes in Fair Value of Investment Properties in the Income Statement: Evidence from Hong Kong. Accounting and Business Research, 39(2), pp. 103-118.

Rasid, S. Z. R., et.al. 2011. Management Accounting Systems in Islamic and Conventional Financial Institutions in Malaysia. Journal of Islamic Accounting and Business Research, 2(2), pp. 153 - 176.

Wahab, N. A \& Rahman, A.R.A. 2011. A Framework to Analyses the Efficiency and Governance of Zakat Institutions. Journal of Islamic Accounting and Business Research, 2(1), pp. 43-62.

Xia, L \& Monroe, K. B. 2010. Is a good deal always fair? Examining the Concepts of Transaction Value and Price Fairness. Journal of Economic Phychology, 31, pp. 884-894. 